To Want to Learn 


\section{To Want to Learn}

\section{INSIGHTS AND PROVOCATIONS FOR}

ENGAGED LEARNING

Second Edition

JACKSON KYTLE

\section{palgrave macmillan}




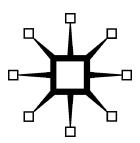

TO WANT TO LEARN

Copyright (C) Jackson Kytle, 2004, 2012.

All rights reserved.

First published in hardcover in 2004 by

PALGRAVE MACMILLAN ${ }^{\circledR}$

in the United States-a division of St. Martin's Press LLC,

175 Fifth Avenue, New York, NY 10010.

Where this book is distributed in the UK, Europe and the rest of the world, this is by Palgrave Macmillan, a division of Macmillan Publishers Limited, registered in England, company number 785998, of Houndmills, Basingstoke, Hampshire RG21 6XS.

Palgrave Macmillan is the global academic imprint of the above companies and has companies and representatives throughout the world.

Palgrave ${ }^{\circledR}$ and Macmillan ${ }^{\circledR}$ are registered trademarks in the United States, the United Kingdom, Europe and other countries.

ISBN 978-0-230-33820-3 ISBN 978-1-4039-7381-8 (eBook)

DOI 10.1057/9781403973818

Library of Congress Cataloging-in-Publication Data is available from the Library of Congress.

A catalogue record of the book is available from the British Library.

Design by Newgen Imaging Systems (P) Ltd., Chennai, India.

First PALGRAVE MACMILLAN paperback edition: July 2012

109876554321

Transferred to Digital Printing in 2012 
For Tari, Josi, Blain, Ethan, Eloise, and Hazel—teachers all! 


\section{Contents}

Acknowledgments $\quad$ ix

Introduction $\quad$ xi

Part I: To Want to Learn 1

1 Educator as Idealist 5

2 Gritty Reality 17

3 Perspectives on Engaged Living 29

Part II: Brain, Mind, and Body 53

4 Psychology of Involvement 63

5 Learning, Motivation, and Biological Systems 87

Part III: Considerations for Learning and Motivation 109

6 Ten Considerations for Better Learning 111

7 Six Considerations to Improve Motivation 137

$\begin{array}{ll}\text { Conclusion } & 149\end{array}$

$\begin{array}{ll}\text { Notes } & 167\end{array}$

$\begin{array}{ll}\text { Index } & 193\end{array}$ 


\section{Acknowledgments}

Without the contributions of friends, colleagues, and critics, my project would have remained on the shelf of good ideas. Among those who inspired me are Professors Al Erdynast, Alan Guskin, Jim Malarkey, Sherry Nicholson, Verbena Pastore, the late Ken Smith and Richard Hathaway, and John Turner. Judith Block McLaughlin helped prepare me to be a college president and, during a welcome sabbatical, gave me a small office at the Harvard Graduate School of Education, where this work began. Dalton Oliver was generous in every conceivable way when I was with Vermont College, as has been my colleague Elizabeth Dickey at The New School, now president of Bank Street College of Education. I have had wonderful teachers like professors Fred Hutchins, Paul Cubeta, Richard Christie, Morton Deutsch, Charles Kadushin, Stanley Schachter, and Leo Srole.

Colleagues provided material support or read portions at different stages and contributed valuable suggestions: Professors Tom Abshire, Bill Hirst, Kathleen Kesson, Melvin Miller, Andy Schmookler, Roben Torosyan, Matthew Porter, and Eric Zencey, and President Richard Schneider of Norwich University. Chapters in the revised edition benefitted from comments by Don Mankin, Roger Brunswick, Scott Richards, Dagmar Grefe, Leonard Hummel, Chris Mooney, and Suzy Stevens. I am always grateful to Arthur Chickering for his ideas and personal example as an engaged scholar. My assistant then at The New School, Aimee Silverman, provided countless hours of proofing and research for the first edition. Professor Ethan Kytle at California State University at Fresno helped with several chapters. I thought of him while framing my arguments for new teachers.

In the book's earliest stage, Brian Ellerbeck at Teachers College Press was the very model of a developmental editor. My first editor, when she was at Palgrave Macmillan, Amanda Johnson Moon, provided generous support. Jen Simington read the first edition carefully and every page benefited from her work. My new editor at Palgrave, Burke Gerstenschlager, inspired me to improve the writing and Kaylan Connally was always helpful with production. I would also like to thank the editorial and production staff at Newgen Knowledge Works for their attention to my manuscript. I am responsible for any problems that remain. 


\section{Introduction}

And the faculty of voluntarily bringing back a wandering attention, over and over again, is the very root of judgment, character, and will. No one is compos sui if he have it not. An education which should improve this faculty would be the education par excellence.

—William James ${ }^{1}$

John Dewey believed that education is a moral undertaking, so let's start with beliefs. I believe in teachers and all the good that comes from learning. I believe that education is a noble profession because educators of all types hold, in their hands, the possibility of improving another person's life. While criticism at teachers comes so easily today, from so many directions, this work to which we commit our lives is worth doing. For this noble calling, I believe we can learn to be better teachers, advisors, and counselors just as we can become better human beings, both to provide examples to our students and to improve the quality of our own short lives.

I have written this small book about big questions in education to provoke and engage educators of every type and age. No silver bullets here and no book in education uses as many different lenses from social psychology to existentialism to neurobiology with which to examine motivation and learning. No book written to educators goes as far from the classroom to look for insights from the theater, sports and hobbies, religious practices, and our lives in different types of social groups. As we go, my reader will hear a steady refrain of criticism for the burden placed on schools and colleges as well as for the plight of the individual in modern times. All these claims sound immodest - to cover so many topics in one book will, of necessity, leave many questions open. Topics as important and complex as this deserve no less.

Motivation and learning are, after all, the core puzzles for teachers and counselors, lying at the very heart of their professional practice. We examine both topics as if holding a Rubik's cube to be twisted and turned from different angles, trying to find solutions for difficult puzzles and brain teasers. Finally, I hope my book is radical in two ways: first, because it looks for the social philosophical roots of problems with today's schools and colleges, and, second, because its cascade of ideas provokes new thinking about teaching and learning.

A book like this would have made my own path as a learner less bumpy and my work as a progressive educator over 30 some years, more effective. It is not, however, a "how to" book that looks at the small pieces; rather, it is a broad critique of conventional thinking about teaching and learning. Neither is it a reductionist drill where 
the author offers disconnected ideas on how to motivate students-as-objects, a view I find too often in traditional education. ${ }^{2}$ And it is not a "self-help" book offering advice without theory or research; although, my readers may find in here practical ideas for improving their practice as well as for building better lives for themselves.

Motivation and learning are problems of living. For a teacher, are there more important topics, either personally or professionally? After all, we educators are supposed to be society's experts. If we do not have this knowledge and cannot guide others to lifelong learning, who will do that work?

Teachers need theory, many theories, to inform their practice, and the ideas in the pages ahead have broad application. The chapters build toward an organizing theory that envisions human beings as pattern seekers and meaning makers whose quality of learning and life depend upon the demand environs chosen for work, learning, and play. I hope my readers will use incisive ideas from William James to Maxine Greene to Ellen Langer to develop their own critique of modern education as well as a working theory of teaching and learning, one to be revised many times over a long career, helping others build a just society.

If I have learned anything while working for progressive colleges, it is to think about the whole more than the parts. To my mind, education and living life are closely intertwined. Direction and quality in life-and quality in education-are steering problems about where to go, what to do (and not do), and how much energy to invest. Moreover, the quality of our work as teachers, counselors, and administrators depends directly on what we know about motivation and learning - and how deeply we think. Why do I say this? I have worked for six colleges and evaluated many others. How we think about learning and motivation are matters under an educator's control whereas elements like budget, class size, or school year are not. Our minds are free if we choose to use them.

One major theme ahead is that we humans respond to clear, consistent, and high expectations. The most powerful tool teachers have, in fact, are the expectations held for their students (and themselves). Better to err on the side of expecting too much (and having to accept falling short) than too little (and not being surprised). We hear about the "tyranny of low expectations" for minority students, which is right if put in odd terms; but holding high expectations applies to teachers, too. Unfortunately, academic standards set by schools of education are uneven, in my experience, and some student-consumers, too, are quick to complain about too much work. As this book tries to model, educators deserve exposure to a range of demanding topics to prepare them as public intellectuals of great curiosity and commitment, as well as engaged citizens who will be leaders in their communities, not just prepared for one type of classroom or school. ${ }^{3}$

\section{Topics}

Of all the problems in living that we humans must confront, motivation is the most important and the least understood. We move toward goals we want, sometimes motivated to self-sacrifice by religious fervor or political purpose. We move away 
from threats and things we fear or dislike, sometimes for reasons that prove short sighted. Rapid, unpredictable changes in attention span and consciousness run us ragged all day long, but we learn to cope. We keep moving through the life-world with a peculiar momentum.

What motivates the countless small acts and endless changes of direction that mark each day of existence? What motivates people to heroic acts? Why do certain actions seem to involve us fully whereas others bring only boredom? How do we understand goals and purposes in motivated acts ranging from studying to passing a course to performing religious devotion to indulging in acts of terrorism? Pulled this way and that by misunderstood forces, we are only rarely aware of our motives. Undergirding motivation and learning are neurobiological topics like the attention system and the nature of human consciousness. How do these function?

So, how does motivation work? What does it mean for education? So many students struggle with school, and education seems always in crisis because, it is said, of unmotivated students who do not want to learn. These immense questions are the subject of this book, and I will use its opening pages to suggest the range of topics we will study, discuss why educators should care, and preview important insights.

This book examines motivation and learning from the diverse perspectives of social psychology and progressive education, existentialism and spirituality, and neurobiology and studies of how the mind works. Difficult moments lie ahead because we want to look far and wide for fresh ideas. But if my reader is patient and keeps going, his or her thinking about learning and life will improve. And he or she will be better prepared to lead exciting schools for a new century.

Motivation is, of course, an academic topic in psychology with side literatures like behavioral physiology and social philosophy. In addition, staying motivated is a topic that is intimate and personal to an extent unusual in social and philosophic studies. After all, staying motivated in the face of distraction and fatigue is a daily challenge for anyone who must construct a life in a problematic world of ambiguous choices. Setting aside instinctual motives, the mechanics of approach and avoidance are not automatic_-rather, conscious, sustained effort is required to build, and rebuild, daily life motivation. And motivation has rhythms not always appreciated. One may enjoy a string of motivated days even without much work, only to find it necessary, suddenly and inexplicably, to have to rebuild the whole project.

Learning, another problem in living, is our second major focus. Learning is our species' most important survival mechanism. If I am good at learning, it is possible to adapt to nearly any circumstance, however dire. If I do not know how to learn, or am unmotivated, survival is compromised. At the very least, quality of life suffers because challenges at work and school are not well used-I do not learn from my mistakes.

Good reasons exist to consider motivation and learning together, to put them in the same phrase, as in the book's title, To Want to Learn. Most higher-order learning is motivated learning. If a learner is unmotivated, learning is boring or painful, and inefficient on both counts. As Edward Deci and his colleagues have shown, authorities resort to extrinsic rewards and punishments like grades to motivate learning rather than look for intrinsic rewards experienced by learners, such as the joy of learning. ${ }^{4}$ 
We will think about motivation and learning in broad terms, but two formspsychological involvement and social engagement-get special attention. A Continental definition of engagement, the French word for an intense commitment to a political or religious cause, connotes moral and political motives not captured by popular American conceptions of involvement or flow, terms that refer to one person's internal psychological state at a point in time. ${ }^{5}$

On the pages ahead, we learn that psychological involvement has many facets, but I am more interested in social engagement as a learned character trait. ${ }^{6}$ If a human life is to mean anything, it should be defined by civic involvement to benefit others and society, not just to gratify personal needs. As philosopher Maxine Greene reminds us, the citizens of Oran in Albert Camus's existentialist novel The Plague do not know how to respond to the spreading threat. ${ }^{7}$ Most escape into diversions, whereas Camus's protagonist, Dr. Rieux, sees it as his duty to stay conscious of the epidemic and to do what he can. We will return to Camus and the existentialist ethic several times.

How to manage involvement and engagement can be learned and this is how schools and colleges can help. Involvement can be defined in opposition to what it is not: It is neither boredom nor an aimless roaming from one activity to the next. Being purposive, it is different from the half-conscious drifting that marks the times when we humans move in and out of a day's activities with no special intensity or satisfaction. The state of intense mental focus, in its purest form, is not frequent, even though a person can learn how to produce learning settings that give rise to it. By way of contrast, social engagement is closer to what Maxine Greene asks of us: to be awake in the world. ${ }^{8}$

Learning settings can be designed to cultivate both attributes and, toward the book's end, I suggest ten considerations for creating engaging schools and six for improving motivation. In fact, among the most important outcomes of an education are the management of one's psychological involvement and social engagement. The harder project, by far, is to cultivate social engagement as a personality trait, a durable disposition extended in time and applied to different behavioral settings, ultimately leading to a life project of achievement, contributions to community and society, and a high quality of life.

Construction metaphors appeal to a progressive educator. Few easy paths appear miraculously through a school or a life. Lives have to be built, plank by plank, floor by floor, and to underestimate the skills and the personal discipline required is easy. While objective conditions of poverty and prejudice reduce one's life chances, few people ever have the resources they need. While life chances are radically different if one wakes up to face a day in Sarajevo versus Scarsdale, human questions of direction and meaning in life are more alike than not, or so I want to believe.

\section{Audiences}

I want the book to be useful to idealistic educators working to create better learning settings, whether new schools and colleges or new programs to involve students within existing schools. The term "educator" will cover many roles in education 
and human services, including teachers in secondary and higher education, school and guidance counselors, as well as academic administration, where I spend most of my career. While our examples come from higher education, where I work, the best ideas should be useful for secondary school education as well as the fast-developing fields of corporate education and adult education.

We need not stop here because, after all, everyone is, or will be, an educator sometime in life, whether as parent, supervisor, coach, or community volunteer. Similarly, the terms "school" and "college" are used in the general sense of organized places and times for learning. Let's think about any intentional program for learning and ask how well that setting is organized to increase motivation and the possibility of learning.

The frames by which educators understand education in all its many forms and venues_our mental models or mindsets_-are changing, as if we find ourselves in an old house whose rooms have functions we no longer quite recognize. After all, learning is increasingly spread across a lifetime and not confined, as it was once, to formal instruction in high school and, for the lucky few, college. The old constraints of time, place, access, and modality by which one became a learned person and a good citizen no longer hold, and the vocabulary is changing too. What we mean by old words like "student," "teacher," "classroom," and "lab" have been challenged by advances in experiential education and new communications technology such as the Internet.

At the same time, schools and colleges will continue as centers of focused learning, at least at certain points in life. ' In that regard, the terms "learning community," "school," and "college" are used interchangeably to suggest that the motivation principles we seek apply to freestanding educational institutions and decentralized units inside large institutions.

Most of all, I hope students beginning long careers find useful ideas. I hope the book's puzzles and dilemmas, insights and provocations, prepare better educators. As I say this, I want to introduce another theme, the need to think about the terms we use to understand education as we use them. As asked of teachers and counselors, let's expand the notion of learner, setting higher goals than graduating from school or earning a high GPA. That is, my book is written to students who, by earning a degree, are working to change their lives, whether they would phrase it that way or not. Adults taking a course at night are closer than young people to the sense of personal transformation buried in that neutered word, "education." They say they want "to get a better job," or being lonely, "to find new friends." Both statements express the unconscious motive of life change - to become a better person, to make a better life.

When it comes to education, I am a hopeless romantic. Critiques of education by John Dewey, Maxine Greene, Theodore Sizer, Henry Giroux, Deborah Meier, Matthias Finger, and Edmund O'Sullivan are well known and, in the pages ahead, we will visit their passionate ideas. Still, it may not help to ask more of a social institution so beleaguered. To raise the stakes feels like piling on. Still, does the modern academy, second in importance only to the family as a character-forming institution, promote optimal development of the whole person? Now we have a challenge! 
Finally, I hope my book appeals to public intellectuals, school board members, and parents involved in educational reform. When I speak in public about living an engaged life, the idea has broad appeal with adult audiences. Self-motivation, one's effectiveness as a lifelong learner and teacher, and quality of psychological experience-all become fascinating topics that are hardly academic.

\section{Writing As A Learning Process}

Uncertainty is a defining characteristic of modernity, and this holds true for economic predictions as well as a writer's bold claims for new theory and exciting reforms. A philosopher would say that knowledge-how it is created, and its truth validity - is falsified in so many ways. For instance, theory is not built with the same organization with which it is published, which will not surprise an active scholar or artist. In truth, the creative process is no different from the way Mary Catherine Bateson argues that character, like the pastry baklava, is built over a period of time by "folding-in" many pieces and disparate ideas. ${ }^{10}$ The path is not straight but iterative-and always imperfect.

The final form of this book is not an accurate representation of the meandering process that produced it. Why do I say this? I want my readers to understand why learning as a process is so important for progressive educators. Not just an epistemological footnote, we educators introduce our students to the creative process. We help them understand that the final products of any period of thinking do not reflect the creative process so vital to research and art.

Academic texts in psychology and philosophy are needlessly intimidating. As we encounter a new field of study, it feels like the poor reader has wandered into a European garden of imposing marble statues. But our visitor lacks any sense of how the figures were produced. Flesh and blood human beings, the carvers, are invisible. The elegance of the finished carvings mislead us as to the years they took to make, all the questions and blind alleys that preceded the final product, not to mention the personal struggle, intruding egotism, and bouts of lost confidence. The final product, a journal article packed with abstractions, is just that - a highly distilled, final representation of a far more interesting process. Hidden and perhaps lost is the idiosyncratic process by which a researcher works through intellectual puzzles, most not new to human affairs.

So, topics like motivation and learning ask us to put aside the scholar's mask, which hides a human being. My work is both public and personal, and each effort informs the other. Although rarely obvious, a book carries forward a subtext about the author's life, especially that of life's unresolved questions and recurring puzzles. Readers are forced to be archaeologists who search the found structure in their hands - the book - for clues about the writer, looking for touches of humanity with which to identify. But earnest readers are soon frustrated because the personal narrative is hidden by academic convention, especially those of the neopositivist, social sciences that struggle with murky boundaries among objective fact, formal theory, and personal experience. 
Why is the personal voice so suspect in intellectual discourse, at least in the social sciences? Like the marking on a college term paper, the "I" is crossed out in scholarly discourse, which reduces the validity and reach of many arguments. Yes, early student writing has an excessive focus on self — and that passionate voice needs tempering. But education has gone too far by banishing the personal voice, which then must struggle to find itself. As powerful as disciplinary inquiry can be, one symptom of the tyranny of scientific reductionism is the loss of the personal. With regard to doing research and writing a book, it seems to me, an informed subjectivity seems preferable to the impossible ideal of an impersonal objectivity.

Think about a seminar I gave at the Harvard Graduate School of Education. As the course unfolded, I found myself comparing that seminar to my class given the year before at tiny Goddard College, a much different academic culture. For Harvard, I asked for a final paper that integrated concepts from the course on college leadership with the student's personal and professional lives (a Goddard-style paper). When I got the papers, they were superior but read as academic exercises. No worries, here, about proofing or quality of writing! Unlike my Goddard students, these were polished performers even as their personal voices were undeveloped. Students felt uncomfortable writing about their experience, their hopes, and fears.

Perfect class exercises were submitted, but to find the real human being behind the mask of a serious student was not easy. In such a way, the best students learn to work the system but remain hidden from the reader and, perhaps, from themselves as human beings. Letting themselves be treated as passive objects inside school, I fear they find it hard to become active subjects outside. The distancing used to cope with 16 years of schooling becomes a personal style of polite disengagement with society.

With topics like motivation and learning, a personal voice is inevitable and quite necessary. I hope that personal examples and asides will not be a distraction but will connect readers to my argument. The point is not my life and how I have used it. Rather, I care most about the puzzles and dilemmas found when studying human motivation and learning, and my experience and reflections might help frame better questions.

Think again about learning as personal process, a familiar theme in progressive education. My quest to understand unresolved issues in my own life eventually led me to search for a theory that explores attention and consciousness in learning, and the stages by which one may develop an engaged life. ${ }^{11}$ As my reading project evolved, my thinking changed. Now I look differently at my own behavior and that of colleagues, friends, and students. For instance, if I thought of it at all, motivation seemed to be all or none. What I understood about human attention and consciousness or awareness was even less informed.

Now I think in terms of gradients, interactions, and transitions among evanescent states of being that are so difficult to define, and impossible to measure. As I imagine it now, the mind is a sand shark, moving endlessly through water, one experience after the other, marked by dramatic shifts in purposefulness and concentration. Certain activities hold the fish's attention for a time, but it keeps moving.

For human beings, our wandering minds seem drawn to events that are novel or complex. We tell jokes and play tricks to "get attention" (one's own and that of 
others) because humor plays directly to the imagination, as do spoken stories, great writing, the theater, and all forms of entertainment. Musicians use rubato, an unresolved chord, or a clever melody to get and hold the listener's attention. The restless mind, that sand shark, keeps roaming.

Now I think differently about reading and writing. Attention and motivation combine to affect learning when reading. An experienced writer learns to work within a narrow band of reader attention and knowledge. Push too hard, the reader is lost. Too little, the reader is bored. Offer up bad sentences that do not engage the reader's imagination, content matters little.

Not a day goes by that I do not think about some facet of motivation and learning even if the impression is as fleeting as an observation made of a street scene in Greenwich Village while walking to work. With rich topics like ours, my colleague Verbena Pastor would say, "One falls in love!" And the beloved is everywhere!

While my personal experience is not the book's subject, wanting to understand motivation as well as improve my own life project has motivated me. I hope the cascade of ideas marched out for duty stimulate doubts and questions with which my readers will examine their experience, their emerging identity as educators, and the lives they are building for themselves out of the questions they, in turn, put before their minds.

\section{A Personal Note}

My interest in motivation comes out of my personal experiences as a student and a teacher in 30 years of higher education. Certainly, I did not have my life sorted out for years and do not now suggest that this "sorting out" is easy, or done to a particular schedule, or is all that durable. None of this stuff about finding meaning in life comes easy! The knowledge needed from social psychology and neurobiology is challenging to sift through. Perhaps the insistence for these topics that I feel today is because of a mix of personal regret that I did not learn certain things earlier in life, the unrecognized value of the topics for schools and society, and my attempts to use language to grab a restless reader's wandering attention.

An indifferent student became a lifelong educator. Other careers choices came open, but my hopeless idealism for education and helping others kept me from other paths. My struggle to become a serious student — to find my self, literally — and my emerging interest in motivation and learning led to work as a teacher, administrator, and trustee for mission-driven colleges like Antioch, Goddard, Sterling, Vermont College, The New School in New York City and HealthCare Chaplaincy.

Without being aware of my motives at the time, I chose these schools because they offered more involved learning and democratic idealism than I had seen in my undergraduate work at Middlebury College or graduate study at Teachers College, Columbia University, where the focus had been academic content and disciplinebased study. I was attracted to the ideas of cooperative and experiential education at Antioch University and Sterling College, and to student-centered learning and holistic education at Goddard College and Vermont College. 


\section{Chapters}

Our chapters fall into three parts: Part I describes the context of contemporary teaching and learning, including the work conditions in school and the role of the teacher. We contrast the great idealism of education in chapter 1 with its gritty reality in chapter 2 . Chapter 3 reviews a range of authors who have written about involvement and engagement such as William James, John Dewy, Abraham Maslow, Mihaly Csikszentmihalyi, Ellen Langer, and Maxine Greene.

Part II, rewritten for the second edition, uses chapter 4 to explore the nature of psychological involvement in life activities - from the mundane to the most riveting. Chapter 5 explores underlying neurobiological systems that support motivation and learning or make both more difficult. We also open questions about the nature of the attention system and human consciousness, arguing that educators need to follow both topics.

Part III applies the most important insights and provocations we have read about to practical problems in schools, colleges, and learning organizations. The narrative is organized around two lists: the first about how to improve learning (chapter 6), the second about select topics in motivation (chapter 7). In the conclusion, we return to general questions and two topics: the problem of self-motivation and the problem of social hope. I also suggest new topics for inquiry and research. 